\title{
PENERAPAN MODEL PEMBELAJARAN KOOPERATIF TIPE NUMBERED HEADS TOGETHER (NHT) UNTUK MENINGKATKAN HASIL BELAJAR PPKN SISWA KELAS VIIIB6 SMP NEGERI 6 SINGARAJA SEMESTER GANJIL TAHUN PELAJARAN 2018/2019
}

\author{
Ni Made Telaga \\ Guru Mata Pelajaran PPKn SMP Negeri 6 Singaraja
}

\begin{abstract}
Abstrak
Tujuan utama penelitian ini adalah untuk memformulasi efektivitas model pembelajaran contextual teaching and learning dalam meningkatkan aktivitas belajar siswa dan prestasi belajar siswa kelas VIII 5 SMP Negeri 2 Singaraja. Secara metodologis penelitian ini menggunakan penelitian tindakan kelas (PTK) yang dilalui dengan tahapan perencanaan, pelaksanaan, observasi dan refleksi. Penelitian ini hanya menggunakan satu kelas. Adapun instrumen yang digunakan dalam penelitian ini adalah peneliti (human instrumen) dengan alat bantu pengumpul data berupa pedoman wawancara, pedoman observasi, tes prestasi belajar dan lembar observasi. Teknik analisis data yang digunakan dalam penelitian ini adalah deskriptif kualitatif.

Hasil penelitian menujukkan model pembelajaran contextual teaching and learning mampu meningkatkan prestasi belajar siswa. Pada siklus I, dari 41 orang siswa hanya 16 orang siswa mendapat nilai di bawah kriteria ketuntasan minimal (KKM) dengan nilai terendah 55, dan mengalami peningkatan pada siklus II, dimana hanya 5 orang siswa yang mendapat nilai di bawah KKM dengan nilai terendah 60 . Nilai rata-rata siswa sebelum dilakukan tindakan adalah sebesar 70,85 dan mengalami kenaikan menjadi 74,42 pada kegiatan siklus I. Pada siklus II penerapan model pembelajaran contextual teaching and learning mampu meningkatkan prestasi belajar siswa menjadi 78,14. Model pembelajaran contextual teaching and learning juga mampu meningkatkan aktivitas belajar siswa, dimana 25 ada pada kategori tuntas pada siklus I dan meningkat menjadi 38 orang pada siklus II. Hal ini disebabkan karena model pembelajaran mampu meingkatkan rasa ingin tahu siswa dan membangun semangat kerjasama siswa.
\end{abstract}

Kata Kunci: Prestasi Belajar, Motivasi Belajar

\section{Abstract}

The main objective of this study was to formulate the effectiveness of contextual teaching and learning learning models in improving student learning activities and learning achievement of class VIII 5 students of Singaraja Middle School 2. Methodologically this study uses classroom action research (CAR) which is passed through the stages of planning, implementation, observation and reflection. This study only uses one class. The instruments used in this study are researchers (human instruments) with data collection tools in the form of interview guidelines, observation guidelines, learning achievement tests and observation sheets. The data analysis technique used in this study is descriptive qualitative.

The results of the study show that the contextual teaching and learning model can improve student learning achievement. In the first cycle, of 41 students only 16 students scored below the minimum completeness criteria (KKM) with the lowest score of 55, and experienced an increase in the second cycle, where only 5 students scored below 
the KKM with the lowest score of 60. The average value of students before the action is 70.85 and increases to 74.42 in cycle I activities. In cycle II the application of contextual teaching and learning learning models can improve student learning achievement to 78.14. The contextual teaching and learning learning model is also able to improve student learning activities, where 25 are in the complete category in the first cycle and increase to 38 people in the second cycle. This is because the learning model is able to increase students' curiosity and build a spirit of student collaboration.

\section{Keywords: Learning Achievement, Learning Motivation}

\section{Pendahuluan}

Pendidikan Pancasila dan Kewarganegaraan (PPKn) merupakan salah satu mata pelajaran wajib yang harus dibelajarkan kepada siswa dari jenjang SD sampai SMA. Melalui pembelajaran PPKn akan dapat dibangun sumber daya manusia (SDM) Indonesia yang tangguh dan berkualitas serta memiliki wawasan dan keterampilan hidup bernegara sesuai dengan tata urutan perundangan yang berlaku. Esensi dari pembelajaran PPKn adalah bagaimana menjadikan siswa sebagai warga Negara yang paham dan sadar akan hak dan kewajiban sebagai warga masyarakat, bangsa dan Negara yang terikat oleh berbagai peranti hukum formal dan adat istiadat. Melalui pendidikan kewarganegaraan siswa dapat belajar dan melatih potensi dirinya secara optimal tentang tata cara hidup, menghadapi masalah dan menyelesaikan masalah berdasarkan peraturan formal yang berlaku, sehingga terwujudnya stabilitas nasional yang kondusif (Lasmawan, 2005). Fungsi mata pelajaran PPKn adalah untuk membentuk warga negara yang cerdas, terampil, dan berkarakter baik serta setia kepada bangsa dan negara Indonesia yang berdasarkan Pancasila dan UUD 1945, sebagai suatu bidang kajian untuk mempersiapkan siswa mampu merefleksikan pengalamannya sendiri dan pengalaman orang lain, mengungkapkan gagasan-gagasan, sedangkan penggunaannya adalah untuk membantu siswa mengenal dirinya, aktif membuat keputusan yang bertanggung jawab pada tingkat pribadi, sosial, menemukan serta menggunakan kemampuan analitis dan imajinatif yang ada dalam dirinya. Mengingat sedemikian pentingnya PPKn bagi siswa dalam memecahkan berbagai persoalan diperlukan suatu strategi yang tepat dalam pembelajaran agar tujuan yang diharapkan dapat dicapai sesuai dengan yang di inginkan. PPKn merupakan salah satu pelajaran yang digemari oleh siswa terkait dengan kegunaannya serta relevansinya dengan kehidupan sehari-hari siswa.

Kenyataannya di lapangan siswa menganggap mata pelajaran PPKn yang membosankan, apa yang dipelajari tidak sesuai dengan kondisi riil di masyarakat dan pembelajarannya lebih bersifat menghafal dari pada bernalar. Kondisi ini berimplikasi pada (1) rendahnya minat belajar Pendidikan Kewarganegaraan; (2) legitimasi penilaian siswa bahwa mata pelajaran Pendidikan Kewarganegaraan sebagai mata pelajaran kelas dua; (3) mata pelajaran yang tidak berguna bagi kehidupan siswa dan menurunnya aktivitas dan hasil belajar Pendidikan Kewarganegaraan. Berbagai permasalahan sebagaimana yang digambarkan di atas juga terjadi dalam pembelajaran PPKn di SMP Negeri 6 Singaraja. Siswa SMP Negeri 6 Singaraja menganggap pelajaran PPKn sebagai pembelajaran yang bersifat 
menghafal dan dapat dipelajari hanya dalam satu malam, pembelajaran yang kurang menarik karena tidak aplikatif, dan tidak berguna bagi kehidupan sehari-hari siswa karena masih kering dari realitas sosial yang tumbuh dan berkembang di masyarakat. Faktor yang menyebabkan permasalahan ini ada yang berasal dari guru. Guru masih menerapkan pembelajaran konvensional dalam pembelajaran. Keterlibatan siswa secara aktif dalam pembelajaran masih kurang. Guru cenderung mendominasi keseluruhan kegiatan pembelajaran. Untuk mengatasi hal ini maka guru seharusnya mampu mengubah model pembelajaran dari yang konvensional menjadi pola pembelajaran yang konstruktif, mampu lebih aktif, kreatif, berinovatif untuk menggunakan modelmodel baru, mampu membuat perencanaan yang baik, menguasai ketrampilan-ketrampilan tertentu, teknik, metode ajar, teori-teori belajar.

Rendahnya hasil belajar siswa di samping disebabkan oleh faktor guru juga disebabkan oleh siswa yaitu siswa jarang mau belajar, sering minta ijin keluar pada saat belajar, sering tidak membuat tugas yang diberikan guru, baik itu tugas mandiri terstruktur maupun tidak terstruktur, siswa jarang mencatat informasi baik dari guru maupun dari temannya, tidak memperhatikan guru (lain-lain pada saat belajar), motivasi rendah untuk belajar. Hal ini menyebabkan pencapaian kompetensi pengetahuan dan ketrampilan berada di bawah kriteria ketuntasan minimal (KKM) yakni sebesar 72. Hal tersebut merupakan temuan-temuan yang terjadi pada mata pelajaran PPKn di kelas VIIIB6 SMPN 6 Singaraja semester ganjil tahun 2018/2019 berdasarkan nilai awal atau penilaian harian pertama. Hasil belajar siswa kelas VIII masih rendah, hal ini tercermin dari hasil penilaian harian 1 pada materi pokok "Memahami Kedudukan dan fungsi Pancasila" masih banyak di bawah KKM dengan ketuntasan belajar $41,02 \%$ berada di bawah ketuntasan klasikal $85 \%$. Sebagian besar siswa yang memperoleh hasil penilaian harian 1 di bawah KBM berada di kelas VIIIB6, yaitu sebanyak 23 siswa dengan rata-rata 68,72 dari 39 orang siswa. Kendala yang peneliti hadapi dalam menerapkan pendekatan saintifik pada kegiatan pembelajaran PPKN disebabkan karena 1) siswa belum terbiasa belajar dengan model pembelajaran berbasis pendekatan saintifik; 2) jumlah siswa dalam satu kelas terlalu banyak. Pada abad pengetahuan ini, kehidupan menuntut kemampuan memecahkan masalah baru secara inovatif, pola perilaku yang unik dan divergen, dan kemampuan kerja sama yang bersinergi dengan sesamanya (Santyasa, 2017). Namun kemasan pembelajaran selama ini belum sepenuhnya mengarah kepada kemampuan-kemampuan yang diharapkan tersebut. Kemasan pembelajaran yang sering ditemukan hanya menitik beratkan pada tuntutan kemampuan hafalan, memecahkan masalah lama, penanaman pola perilaku yang konfronmistis dan seragam dengan pola pengajaran bernuansa kompetitif dan persaingan (Santyasa, 2017). Pola perilaku keseragaman dihasilkan dalam pola pembelajaran semacam itu, dengan harapan akan menghasilkan keteraturan, ketertiban, ketaatan, dan kepastian.

Bagi pebelajar yang kurang mampu, suasana kompetitif sangat mengurangi motivasi belajarnya dan senantiasa menjadi siksaan psikologis mereka. Oleh sebab itu, para guru hendaknya menghindari dan mengantisipasi agar tidak memunculkan suasana kompetitif dalam pembelajaran, tetapi perlu menciptakan suasana kelas yang penuh toleransi, membuat 
pebelajar saling membantu satu sama lain, dan memfasilitasi mereka agar dapat sukses bersama secara akademik. Ini berarti perlunya rancangan pembelajaran yang bernuansa kolaborasi yang menghargai segala bentuk keragaman peserta didik. Dalam belajar, potensi keragaman peserta didik akan menghasilkan sinergi yang pada akhirnya bermuara pada produk yang optimal (Santyasa, 2017). Berdasarkan permasalahan di atas, maka perlu diterapkan suatu model pembelajaran inovatif bernuansa kolaborasi yang bersifat kontekstual, untuk membantu siswa memahami konsep PPKn serta aplikasinya di dalam kehidupan seharihari. Salah satu kemasan pembelajaran yang memiliki aspek kolaborasi adalah kemasan pembelajaran berorientasi pembelajaran kooperatif. Hill dan Hill (1993) mengemukakan dua unsur yang sangat penting dalam berbagai aktivitas kooperatif, yaitu kesamaan tujuan dan saling ketergantungan secara positif. Jadi, yang lebih ditekankan pada proses pembelajaran kooperatif adalah kooperasi daripada kompetisi, saling ketergantungan daripada kemandirian, mengutamakan kepercayaan pada para siswa, dan menganggap bahwa siswa memiliki kemampuan sosial dalam belajar bersama untuk mencapai tujuannya. Ada banyak macam pembelajaran kooperatif yang pernah dikembangkan, salah satunya adalah tipe number heads together (NHT).

Melihat kesenjangan antara harapan-harapan yang telah disampaikan dengan kenyataan lapangan sangat jauh berbeda, agar masalah ini tidak berlarut-larut dan segera dapat dipecahkan dalam upaya memperbaiki mutu pendidikan utamanya pada mata pelajaran PPKn, sangat perlu kiranya dilakukan perbaikan cara pembelajaran. Salah satunya adalah perbaikan pembelajaran dengan menggunakan model kooperatif tipe numbered heads together (NHT). Hal ini dicobakan mengingat adanya penelitian terdahulu yang dilakukan oleh Ni Ketut.Sundaeni,S.Pd.PKn (2017), KA Krisnayanti (2018), Destra Putri Dewi (2015) karena itu penelitian tindakan kelas ini penting untuk dilaksanakan guna meningkatkan hasil belajar PPKn siswa kelas VIIIB6 di SMP Negeri 6 Singaraja melalui penerapan model kooperatif tipe NHT di semester ganjil tahun pelajaran 2018/2019.

\section{Metode Penelitian}

Penelitian ini merupakan penelitian tindakan kelas yang dilaksanakan untuk dua siklus. Masingmasing siklus terdiri dari empat tahapan, yaitu: 1) perencanaan, 2) pelaksanaan tindakan, 3) observasi dan evaluasi tindakan, dan 4) refleksi. Materi yang dibahas pada siklus I dan II adalah KD 3.2. Merasionalkan makna,kedudukan dan fungsi UndangUndang Dasar Negara Kesatuan Republik Indonesia Tahun 1945, serta peraturan hukum lainnya dalam sistem hukum nasional. Siklus I membahas kedudukan dan makna Pembukaan UUD NKRI Tahun 1945 serta kedudukan dan fungsi UUD NKRI Tahun 1945 yang dilakukan dalam tiga kali pertemuan dan siklus II membahas Peraturan Perundang-Undangan dalam sistem Hukum Nasional dan UUD NKRI Tahun 1945 yang dilakukan dalam tiga kali pertemuan.

Subyek dalam penelitian ini adalah siswa kelas VIIIB6 SMP Negeri 6 Singaraja semester ganjil tahun pelajaran 2018/2019 yang berjumlah 39 orang yang terdiri dari 27 orang lakilaki dan 12 orang perempuan. Sedangkan objek penelitiannya adalah hasil belajar PPKn siswa akibat penerapan model pembelajaran 
kooperatif tipe numbered heads together. Adapun instrumen yang digunakan dalam penelitian ini adalah peneliti (human instrumen) dengan alat bantu pengumpul data berupa pedoman wawancara, pedoman observasi, tes prestasi belajar dan lembar observasi. Data yang diperoleh diolah dan dianalisis dengan teknik analisis deskriptif kuantitatif. Hasil analisa data berupa rata-rata hasil belajar siswa, serta persentase ketuntasan belajar.

\section{Hasil Dan Pembahasan \\ Pelaksanaan Tindakan Siklus I dan Siklus II}

Penelitian ini merupakan penelitian tindakan kelas yang dilaksanakan untuk dua siklus. Tindakan yang diterapkan pada penelitian ini adalah penerapan model pembelajaran kooperatif tipe numbered heads together untuk meningkatkan hasil belajar PPKn siswa. Subjek dari penelitian ini adalah siswa kelas VIIIB6 SMP Negeri 6 Singaraja tahun pelajaran 2018/2018 dengan jumlah subyek 39 orang. Objek penelitiannya adalah hasil belajar PPKn siswa akibat penerapan model pembelajaran kooperatif tipe numbered heads together. Terdapat empat tahapan yang dilakukan pada setiap siklus, yaitu 1) perencanaan, 2) pelaksanaan tindakan, 3) observasi dan evaluasi tindakan, dan 4) refleksi. Untuk siklus I, materi yang dibahas adalah kedudukan dan makna Pembukaan UUD NKRI Tahun 1945 serta kedudukan dan fungsi UUD NKRI Tahun 1945. Alokasi waktu untuk siklus I adalah 6 jam pelajaran atau $3 \mathrm{x}$ tatap muka. Sedangkan untuk siklus II materi yang dibahas adalah Peraturan Perundang-Undangan dalam sistem Hukum Nasional dan UUD NKRI Tahun 1945 dengan alokasi 6 jam pelajaran atau $3 \mathrm{x}$ tatap muka. Secara lengkap berikut deskripsi tindakan masing-masing siklus.

Proses pembelajaran siklus I dilaksanakan dalam tiga kali tatap muka dengan rincian sebagai berikut. Pertemuan pertama dilaksanakan pada hari Rabu, 29 Agustus 2018 dengan membahas materi kedudukan dan makna Pembukaan UUD NKRI Tahun 1945 melalui kegiatan diskusi kelompok. Pertemuan kedua dilaksanakan hari Rabu, 5 September 2018 dengan membahas materi serta kedudukan dan fungsi UUD NKRI Tahun 1945 melalui kegiatan diskusi kelompok. Pertemuan ketiga dilaksanakan hari Rabu, 12 September 2018 dengan mengadakan tes akhir sikus I. Siswa diberikan tes hasil belajar PPKn materi siklus I sebanyak 10 soal uraian. Tujuan pembelajaran siklus I adalah melalui kegiatan belajar kooperatif tipe numbered heads together, siswa dapat (1) menganalisis kedudukan dan makna Pembukaan UUD NKRI Tahun 1945; (2) mendeskripsikan kedudukan dan fungsi UUD NKRI Tahun 1945. Sebelum pertemuan pertama siklus I, peneliti memberikan pembekalan kepada siswa mengenai aturan pembelajaran dengan menggunakan model pembelajaran kooperatif tipe numbered heads together dan proses belajar-mengajar yang akan dilakukan. Guru melakukan pembagian kelompok belajar secara heterogen yang terdiri atas 4-5 orang dalam satu kelompok belajar.

Kegiatan pendahuluan dalam pembelajaran diawali dengan memusatkan perhatian siswa dengan mengucapkan salam pembuka, berdoa sebelum memulai pembelajaran, mengecek kehadiran siswa, kesiapan ruangan belajar termasuk sarana dan prasarana pembelajaran serta persiapan siswa dalam mengikuti pelajaran. Selanjutnya guru menyampaikan tujuan 
pembelajaran dan memberikan motivasi dengan menyanyikan lagu nasional. Guru memberikan apersepsi dengan menunjukkan gambar Burung Garuda Pancasila. Siswa mengamati gambar burung Garuda dan memberikan pendapat tentang gambar tersebut. Kemudian siswa diarahkan membentuk kelompok heterogen yang terdiri atas 45 orang dan guru menyampaikan rencana kegiatan. Kegiatan inti pembelajaran mengikuti tahapantahapan pembelajaran dalam model numbered heads together yang meliputi tahap penomoran, tahap mengajukan pertanyaan, tahap berpikir bersama, dan tahap menjawab. Dalam model pembelajaran kooperatif tipe numbered heads together, siswa dibagi menjadi beberapa kelompok dan setiap anggota kelompok diberi nomor kepala. Selanjutnya di setiap kelompok dilakukan diskusi untuk menjawab permasalahan atau untuk melakukan suatu kegiatan. Dari hasil kegiatan tersebut guru mengundi nama kelompok dan nomor anggota kelompok yang harus menjawab pertanyaan atau mempresentasikan kegiatan. Berkaitan dengan hal ini, maka setiap anggota kelompok dituntut untuk bekerja sama karena jawaban atau presentasi dari perwakilan anggota kelompok akan menjadi generalisasi kemampuan atau nilai kelompok.

Pada kegiatan penutup pembelajaran guru mengajak siswa untuk bersama-sama menyimpulkan materi pembelajaran. Guru melakukan refleksi dengan peserta didik atas manfaat yang didapatkan dari proses pembelajaran yang dilakukan. Guru memberikan umpan balk atas proses pembelajaran dan hasil laporan individu secara keseluruhan. Di akhir pembelajaran, gru memberikan kuis kepada siswa, kemudian memberikan kesempatan pada siswa untuk bertanya apabila ada yang belum dimengerti. Guru menyampaikan rencana pembelajaran berikutnya. Kegiatan pembelajaran diakhir dengan berdoa dan mengucapkan salam penutup.

Proses pembelajaran siklus II dilaksanakan dalam tiga kali tatap muka dengan rincian sebagai berikut. Pertemuan pertama dilaksanakan pada hari Rabu, 19 September 2018 dengan membahas materi Peraturan PerundangUndangan dalam sistem Hukum Nasional. Pertemuan kedua dilaksanakan hari Rabu, 26 September 2018 dengan membahas materi UUD NKRI Tahun 1945. Pertemuan ketiga dilaksanakan hari Rabu, 10 Oktober 2018 dengan mengadakan tes akhir sikus II. Siswa diberikan tes hasil belajar PPKn materi siklus II sebanyak 10 soal uraian. Tujuan pembelajaran siklus II adalah melalui kegiatan belajar kooperatif tipe numbered heads together, siswa dapat (1) menjelaskan Peraturan Perundang-Undangan dalam sistem Hukum Nasional; melaksanakan dan mempertahankan UUD NKRI Tahun 1945. Sebelum pertemuan pertama siklus II, peneliti kembali memberikan pembekalan kepada siswa mengenai mengenai aturan pembelajaran dengan menggunakan model pembelajaran kooperatif tipe numbered heads together dan proses belajar-mengajar yang akan dilakukan berdasarkan hasil refleksi siklus I. Pembagian kelompok belajar secara heterogen yang terdiri atas 4-5 orang dalam satu kelompok belajar telah dilakukan pada siklus I.

Kegiatan pendahuluan dalam pembelajaran diawali dengan memusatkan perhatian siswa dengan mengucapkan salam pembuka, berdoa sebelum memulai pembelajaran, mengecek kehadiran siswa, kesiapan ruangan belajar termasuk sarana dan prasarana pembelajaran serta persiapan 
siswa dalam mengikuti pelajaran. Selanjutnya guru menyampaikan tujuan pembelajaran dan memberikan motivasi dengan menyanyikan lagu nasional. Guru memberikan apersepsi tentang materi yang akan dibahas dengan menunjukkan gambar dan mengarahkan siswa untuk memberikan pendapat tentang hal tersebut. Kemudian siswa diarahkan membentuk kelompok heterogen yang terdiri atas 4-5 orang dan guru menyampaikan rencana kegiatan. Kegiatan inti pembelajaran mengikuti tahapan-tahapan pembelajaran dalam model numbered heads together yang meliputi tahap penomoran, tahap mengajukan pertanyaan, tahap berpikir bersama, dan tahap menjawab. Dalam model pembelajaran kooperatif tipe numbered heads together, siswa dibagi menjadi beberapa kelompok dan setiap anggota kelompok diberi nomor kepala. Selanjutnya di setiap kelompok dilakukan diskusi untuk menjawab permasalahan atau untuk melakukan suatu kegiatan. Dari hasil kegiatan tersebut guru mengundi nama kelompok dan nomor anggota kelompok yang harus menjawab pertanyaan atau mempresentasikan kegiatan. Berkaitan dengan hal ini, maka setiap anggota kelompok dituntut untuk bekerja sama karena jawaban atau presentasi dari perwakilan anggota kelompok akan menjadi generalisasi kemampuan atau nilai kelompok.

$$
\text { Pada kegiatan penutup }
$$

pembelajaran guru mengajak siswa untuk bersama-sama menyimpulkan materi pembelajaran. Guru melakukan refleksi dengan peserta didik atas manfaat yang didapatkan dari proses pembelajaran yang dilakukan. Guru memberikan umpan balk atas proses pembelajaran dan hasil laporan individu secara keseluruhan. Di akhir pembelajaran, gru memberikan kuis kepada siswa, kemudian memberikan kesempatan pada siswa untuk bertanya apabila ada yang belum dimengerti. Guru menyampaikan rencana pembelajaran berikutnya. Kegiatan pembelajaran diakhir dengan berdoa dan mengucapkan salam penutup.

\section{Hasil Pelaksanaan Tindakan Siklus I dan Siklus II}

Materi yang dibahas pada siklus I adalah kedudukan dan makna Pembukaan UUD NKRI Tahun 1945 serta kedudukan dan fungsi UUD NKRI Tahun 1945. Data yang dicari dalam penelitian ini adalah data hasil belajar PPKn yang dikumpulkan dengan menggunakan tes hasil belajar PPKn. Sebelum dilakukan tindakan pada siklus I, terlebih dahulu dilakukan tes awal yang berbentuk tes uraian untuk mengetahui tingkat pengetahuan siswa terhadap bahan kajian yang dibahas. Setiap akhir tatap muka dilakukan kuis berbentuk tes uraian untuk mengetahui tingkat pemahaman siswa terhadap materi yang baru dibahas. Berdasarkan hasil tes awal siswa, didapatkan data bahwa pengetahuan awal siswa mengenai materi yang akan dibahas sangat rendah dengan nilai ketuntasan $41,02 \%$. Ini menunjukkan bahwa siswa belum mempunyai pengetahuan awal tentang materi yang akan dibahas. Pembelajaran dalam siklus I dilakukan dengan mengikuti tahapan-tahapan model pembelajaran kooperatif tipe numbered heads together. Setelah pembelajaran pada siklus I selesai, siswa diberikan tes hasil belajar PPKn materi siklus I jenis soal uraian. Ringkasan data hasil belajar PPKn siswa pada siklus I disajikan pada tabel 3.1 berikut. 


\begin{tabular}{|l|l|}
\hline Jumlah Siswa & 39 \\
\hline Total Nilai & 2960 \\
\hline Rata-Rata & 75,89 \\
\hline Jumlah Siswa Tuntas & 33 \\
\hline Jumlah Siswa Tidak Tuntas & 6 \\
\hline Ketuntasan & $76,92 \%$ \\
\hline
\end{tabular}

Tabel 3.1. Data Hasil Belajar PPKn Siswa pada Siklus I

Berdasarkan data Tabel 4.1, hasil belajar PPKn siswa pada siklus I tergolong tidak tuntas dengan rata-rata skor 75,89. Ketuntasan belajar (\% siswa yang skornya $\geq 72$ ) baru mencapai $76,92 \%$, hal ini masih tergolong jauh dari ketuntasan klasikal yang ditetapkan yakni sebesar $85 \%$. Ini artinya, secara klasikal hasil belajar PPKn siswa belum mencapai ketuntasan atau siswa dengan skor lebih besar atau sama dengan $72(\geq$ 72) belum mencapai $85 \%$ dari total 39 orang siswa. Penerapan model pembelajaran numbered heads together pada siklus I, cukup mendapat sambutan dari kalangan siswa, walupun awalnya siswa masih terasa asing dengan pembelajaran NHT. Paling tidak pembelajaran sudah tidak berpusat pada guru dan terlihat siswa cukup antusias saat berdiskusi menyelesaikan tugas yang dibebankan. Rata-rata skor hasil belajar PPKn siklus I sebesar 75,89 tergolong belum tuntas. Demikian pula dengan ketuntasan belajar siswa baru mencapai $76,92 \%$ dari 39 orang siswa. Tindak lanjut pada siklus II dilakukan dengan mempertimbangkan hasil refleksi tindakan pada siklus I. Selanjutnya, dilakukan beberapa penyempurnaan yang bertujuan untuk meningkatkan perolehan skor hasil belajar PPKn siswa. Untuk pembelajaran pada siklus II dilakukan pada materi kedudukan dan fungsi UUD NKRI Tahun 1945. Strategi pembelajaran yang dilakukan, secara umum sama dengan siklus I, namun dilakukan beberapa penyempurnaan, antara lain: (1) materi yang akan dibahas lebih awal diberikan kepada siswa, dengan maksud untuk memberikan kesempatan kepada siswa mempelajari lebih awal di rumah, (2) sebelum kegiatan belajar mengajar dimulai, siswa diberikan penjelasan tentang strategi berdiskusi dengan pembagian tugas yang jelas, sehingga pembelajaran menjadi efektif dan efesien.

Pembelajaran pada siklus II dilakukan untuk materi kedudukan dan fungsi UUD NKRI Tahun 1945. Pembelajaran dalam siklus II dilakukan dengan mengikuti tahapan-tahapan model pembelajaran kooperatif tipe numbered heads together. Setelah pembelajaran pada siklus II selesai, siswa diberikan tes hasil belajar PPKn untuk materi siklus II dengan jenis soal uraian. Ringkasan data hasil belajar PPKn siswa pada siklus I disajikan pada Tabel 3.2 berikut.

\begin{tabular}{|l|l|}
\hline Jumlah Siswa & 39 \\
\hline Total Nilai & 3345 \\
\hline Rata-Rata & 85,77 \\
\hline Jumlah Siswa Tuntas & 39 \\
\hline Jumlah Siswa Tidak Tuntas & 4 \\
\hline
\end{tabular}


Ketuntasan

92,30\%

Tabel 3.2. Data Hasil Belajar PPKn Siswa pada Siklus II

Berdasarkan data Tabel 4.2, hasil belajar PPKn siswa pada siklus II, tergolong tuntas dengan rata-rata skor 85,77 Ketuntasan belajar (\% siswa yang skornya $\geq 72$ ) telah mencapai $92,30 \%$. Secara umum, hasil ini meningkat jika dibandingkan dengan siklus I. Berdasarkan hasil penelitian siklus II yang menunjukkan bahwa hasil belajar PPKn dan ketuntasan belajar meningkat dari siklus I, maka hal penting yang perlu diperhatikan pada setiap pembelajaran adalah menciptakan kondisi pembelajaran yang tepat, kondusif, ramah, gembira, kontekstual dan demokratis. Melalui pemberian bimbingan secara intensif baik yang dilakukan guru maupun oleh teman sekelompok, maka tampak ada peningkatan pada aspek kognitif, demikian juga ketuntasan secara klasikal. Terlihat juga bahwa pada siswa tidak terjadi perbedaan antar individu, sekaligus menumbuhkan kesadaran berinteraksi sosial dalam upaya mewujudkan pembelajaran bermakna. Hal ini sesuai dengan pembelajran kooperatif yang menitik beratkan pada tujuan pembelajaran akan tercapai jika siswa lain dalam kelompok yang sama dapat mencapai tujuan mereka bersama.

Untuk menentukan keberhasilan tindakan penelitian ini, maka perlu dilakukan perbandingan data hasil penelitian yaitu data hasil belajar PPKn. Kriteria keberhasilan tindakan untuk hasil belajar PPKn minimal memiliki rata-rata hasi belajar 72 dengan ketuntasan klasikal $85 \%$ dari 39 orang siswa di kelas VIIIB6 tersebut. Ringkasan hasil penelitian siklus I dan siklus II disajikan pada Tabel 3.3 berikut. Ringkasan hasil belajar PPKn siklus I dan II

\begin{tabular}{|l|l|l|l|}
\hline Aspek & Siklus I & Siklus II & Kenaikan \\
\hline Rata-rata & 75,89 & 85,64 & 9,35 \\
\hline Ketuntasan & $76,92 \%$ & $92,30 \%$ & $15,38 \%$ \\
\hline
\end{tabular}

Tabel 3.3. Ringkasan hasil belajar PPKn siklus I dan II

Berdasarkan Tabel 4.3, tampak bahwa rata-rata hasil belajar PPKn siswa siklus I sebesar 75,89, dan ratarata siklus II 85,64 meningkat sebesar 9,35.pada siklus I ketuntasan hasil belajar PPKn adalah 76,92\%, pada siklus II ketuntasannya hasil belajar PPKn menjadi 92,30\% , meningkat sebesar $15,38 \%$. Hasil penelitian ini menunjukkan bahwa penerapan model pembelajaran kooperatif tipe NHT dapat meningkatkan hasil belajar PPKn siswa kelas VIIIB6 SMP N 6 Singaraja tahun pelajaran 2018/2019. Profil perbandingan rata-rata hasil belajar PPKn siswa pada siklus I dan II disajikan pada garif 3.1. 


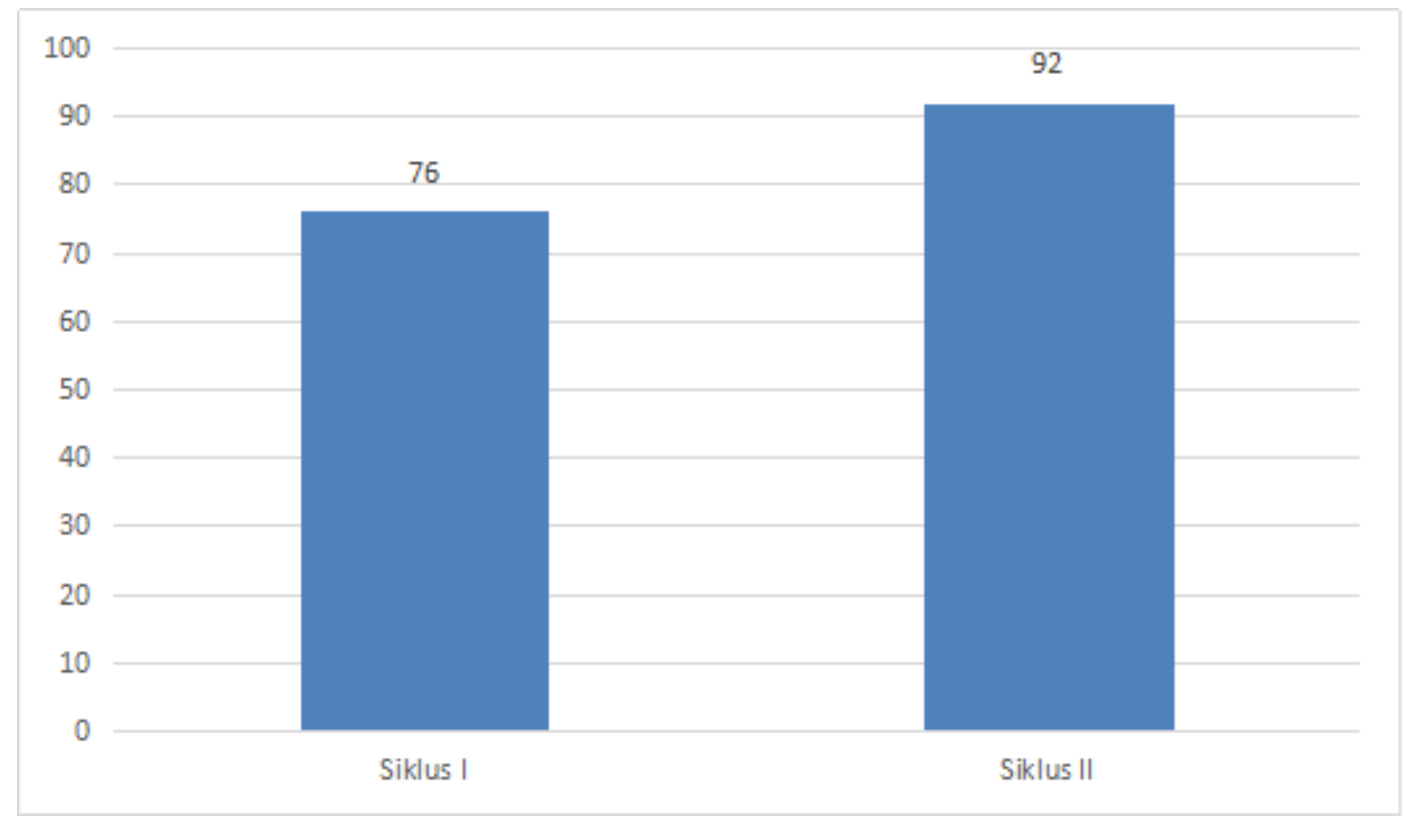

Grafik 3.3. Profil perbandingan rata-rata hasil belajar PPKn siklus I dan II

\section{Penutup}

\section{Kesimpulan}

Berdasarkan hasil analisis data dan pembahasan, dapat ditarik simpulan sebagai berikut. Penerapan model pembelajaran kooperatif tipe numbered heads together dapat meningkatkan hasil belajar PPKn siswa kelas VIIIB6 SMP Negeri 6 Singaraja tahun pelajaran 2018/2019. Rata-rata hasil belajar PPKn siswa siklus I adalah 76 dengan ketuntasan $77 \%$ meningkat rata-rata sebesar 9.35 ke siklus II menjadi 86 dengan ketuntasan 92\% meningkat sebesar 15,38\%. Penerapan model pembelajaran kooperatif tipe numbered heads together juga mampu membangun motivasi belajar siswa dan keterampilan bekerjasama. Hal ini disebabkan karena model pembelajaran kooperatif tipe numbered heads together memberikan keleluasaan kepada siswa untuk saling berbagi dan bekerjasama menyelesaiakn tugas-tugas yang diberikan oleh guru.

\section{Saran}

Berdasarkan hasil penelitian ini, disampaikan saran sebagai berikut: (1) diharapkan kepada guru untuk menerapkan model pembelajaran kooperatif tipe numbered head togeteher sebagai salah satu alternatif dalam melaksanakan pembelajaran yang lebih bermakna, menantang dan berbasis nilai bagi siswa, dan (2) model pembelajaran kooperatif tipe numbered heads together mampu memberikan motivasi kepada semua siswa untuk menyukai pelajaran PPKn, dan menanamkan pemahaman bahwa PPKn amat berguna dalam kehidupan seharihari untuk menjadi warga negara yang baik dan nasionalis.

\section{Daftar Pustaka}

Departemen Pendidikan Nasional. (2006). Kurikulum Kompetensi Kebijaksanaan Umum Pendidikan Dasar dan Menengah. Jakarta :Pusat Kurikulum- Badan Penelitian dan pengembangan 
Dimyati dan Mudjiono. (2006). Belajar dan Pembelajaran. Jakarta: Rineka Cipta

Djamarah. (1994). Prestasi belajar dan kompetensi guru. Surabaya: Usaha Nasional.

Hill, S. \& Hill, T. (1993). The collaborative classroom: A guide to co-operative learning. Malvem Rood Australia: Eleanor Curtain Publishing.

Ibrahim, M. (2000). Pembelajaran kooperatif. Surabaya: University Press.

Igbo, J. N., Ikechukwu, R. F. E. V., \& Victoria, O. (2015). Conception of collaborative learning in secondary schools: Relationship with self-efficacy belief and academic achievement. IMPACT: International Journal of Research in Humanities, Arts, and Literature, 3(9), 65-78. Terdapat pada

http://oaji.net/articles/2015/488-

1444304118.pdf. Diakses 02 Oktober 2016.

Isjoni. (2007). Pendidikan sebagai investasi masa depan. Jakarta: Yayasan Obor Indonesia

Johnson, D.W. \& Johnson, R.T. (1994). Learning together and alone: Cooperative, competitive, and individualistic learning (4th Ed.). Needham Heights, MS: Allyn \& Bacon.

Kagan. (2000). Cooperative learning structure: Numbered Heads together. (online). Diakses 15 September 2018 dari http://www.eazhull.org.uk/nlc/nu mbered_heads.htm.

Lasmawan, W. (2005). Pendidikan dalam Konteks Globalisasi. Singaraja: IKIP Negeri Singaraja.

Lie, Anita. (2002). Cooperative Learning (Memperaktikkan Cooperative Learning di Ruang- ruang Kelas). Jakarta : PT. Gramedia Widiasarana Indones

Rahayu, Y. S. (2006). Pembelajaran MIPA Bahasa Inggris (IMERSI). Surabaya: Makalah yang Diseminarkan pada Workshop Biologi tgl 16 Desember 2006

Sadia, I W. (2007). Pengembangan kemampuan berpikir formal siswa SMA melalui penerapan model pembelajaran "problem based learning" dan "cycle learning" dalam pembelajaran fisika. Jurnal Pendidikan dan Pengajaran. 40(1): $1-20$.

Santyasa, I W. (2008). Model-model pembelajaran inovatif. Makalah. Disajikan dalam PLPG bagi para guru TK, SD, SMP, dan SMA di Provinsi Bali 24-30 November 2008. Universitas Pendidikan Ganesha.

Santyasa, I W. (2017). Pembelajaran inovatif. Singaraja: Undiksha Press

Slavin, R. E. (1995). Cooperative learning: Theory, research, and practive. Second edition. Boston: Allyn and Bacon.

Slavin, R. E. (2011). Psikologi pendidikan: Teori dan praktek edisi kesembilan jilid 1. Terjemahan Samosir, M. Educational psychology: Theory and practice, 9th ed. (2009) Jakarta: PT Indeks.

Snowman, J., McCown, R, \& Biehler, R. (2009). Psychology applied to teaching. (12 ed). New York: Houghton Mifflin Company.

Suastra, I. W. (2009). Pembelajaran sains terkini. Singaraja: Universitas Pendidikan Ganesha.

Sudjana, N. (2000). Dasar-dasar proses belajar mengajar. Bandung: Sinar Baru Algensindo.

Widodo, Joko (2007). Learning Organization: Piranti Pemimpin 
Volume 1, Nomor 1 April 2019

ISSN : 2656-9639 (Cetak)

Visioner. Malang: Bayumedia Publishing

Trianto. (2007). Mendesain model pembelajaran inovatif progresif. Jakarta: Prestasi Pustaka.

Tryana, A. (2008). Penerapan model pembelajaran kooperatif numbered heads togeteher (NHT). Jakarta: Prestasi Pustaka

Yamin, H. M. (2008). Desain Pembelajaran Tingkat Satuan Pendidikan. Jakarta: Gaung Persada Press.

Zainul \& Nasution. (2001). Penilaian hasil belajar. Jakarta: Dirjen Dikti. 